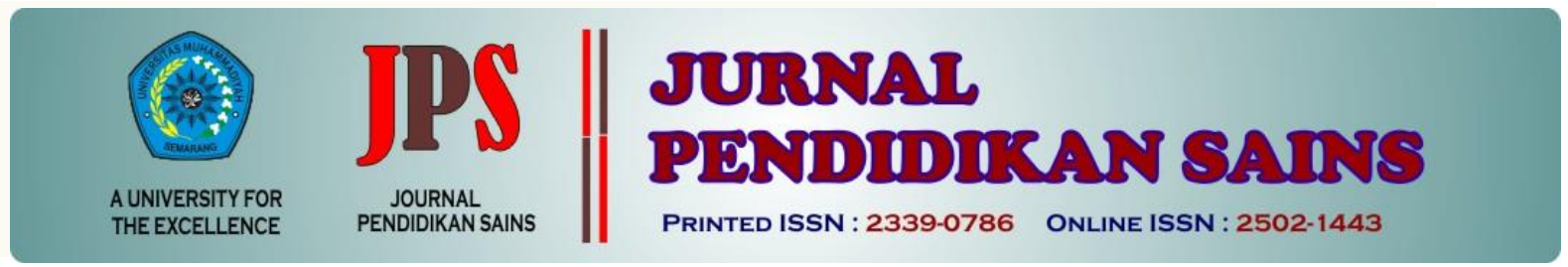

http://jurnal.unimus.ac.id/index.php/JPKIMIA

\title{
IDENTIFIKASI GAYA BELAJAR MODEL KOLB TERHADAP PESERTA DIDIK MAN II YOGYAKARTA
}

\author{
Oleh: Gita Melinda, Asih Widi Wisudawati \\ Prodi Pendidikan Kimia,Universitas Islam Negeri Sunan Kalijaga, Indonesia (55221)
}

\begin{tabular}{|c|c|c|}
\hline \multicolumn{2}{|c|}{ Article history } & \multirow{2}{*}{$\begin{array}{l}\text { Abstract } \\
\text { Penelitian ini bertujuan untuk mengidentifikasi gaya } \\
\text { belajar peserta didik dan mengetahui korelasi antara }\end{array}$} \\
\hline Submission & : 2017-10-19 & \\
\hline Revised & $:-$ & $\begin{array}{l}\text { belajar peserta didik dan mengetahui korelasi antara } \\
\text { kemampuan spasial dan gaya belajar peserta didik pada mata }\end{array}$ \\
\hline Accepted & : 2018-03-07 & $\begin{array}{l}\text { pelajaran kimia. Metode yang digunakan adalah metode } \\
\text { deskriptif dengan pendekatan kuantitatif. Variabel dalam } \\
\text { penelitian ini adalah gaya belajar yang meliputi diverger, }\end{array}$ \\
\hline \multicolumn{2}{|l|}{ Keyword } & $\begin{array}{l}\text { assimilator, converger, dan accomodator. Subjek dalam } \\
\text { penelitian ini sejumlah } 52 \text { peserta didik XI MIPA MAN II }\end{array}$ \\
\hline \multicolumn{2}{|c|}{$\begin{array}{l}\text { Gaya belajar model Kolb, diverger, } \\
\text { converger, assimilator, accomodator }\end{array}$} & $\begin{array}{l}\text { Yogyakarta tahun ajaran } 2016 / 2017 \text { dan } 270 \text { peserta didik dari } 6 \\
\text { sekolah yang ada di Yogyakarta. Teknik pengumpulan data } \\
\text { menggunakan angket KLSI (Kolb Learning Style Inventory). } \\
\text { Adapun teknik analisis yang digunakan adalah statistik } \\
\text { deskriptif. Hasil penelitian menunjukkan bahwa peserta didik } \\
\text { dari MAN II Yogyakarta memiliki kecenderungan pada gaya } \\
\text { belajar assimilator sebanyak } 19 \text { peserta didik atau } 36,5 \% \text {, gaya } \\
\text { belajar diverger sebanyak } 17 \text { peserta didik atau } 32,6 \% \text {, gaya } \\
\text { belajar converger sebanyak } 11 \text { peserta didik atau } 21,2 \% \text {, dan } \\
\text { gaya belajar accomodator sebanyak } 5 \text { peserta didik atau } 9,6 \% \text {. } \\
\text { Peserta didik dari } 6 \text { sekolah di Yogyakarta memiliki } \\
\text { kecenderungan pada gaya belajar assimilator sebanyak } 96 \\
\text { peserta didik atau } 35,5 \% \text {, gaya belajar diverger sebanyak } 93 \\
\text { peserta didik atau } 34,4 \% \text {, gaya belajar converger sebanyak } 53 \\
\text { peserta didik atau } 19,6 \% \text { dan gaya belajar accomodator } \\
\text { sebanyak } 28 \text { peserta didik atau 10,3\%. Terdapat korelasi antara } \\
\text { kemampuan spasial dan gaya belajar yang ditunjukkan oleh } 19 \\
\text { peserta didik XI MIPA MAN II Yogyakarta memiliki nilai } \\
\text { kemampuan spasial dan nilai ulangan harian hidrokarbon } \\
\text { diatas nilai KKM materi hidrokarbon sesuai dengan gaya } \\
\text { belajar yang dimiliki peserta didik yaitu gaya belajar tipe } \\
\text { assimilator. }\end{array}$ \\
\hline
\end{tabular}

*Corresponding Author

Nama : Gita Melinda

Lembaga : Universitas Islam Negeri Sunan Kalijaga

Email : gitamelinda8@gmail.com 


\section{PENDAHULUAN}

Setiap individu selalu menghendaki adanya kemajuan dalam kehidupan di masa depan, kemajuan tersebut dapat dilakukan dengan adanya pengembangan diri melalui pendidikan. Pendidikan merupakan acuan utama untuk mengembangkan potensi yang ada dalam diri manusia. Pada proses pendidikan, kegiatan belajar merupakan bagian dari pendidikan. Hal ini berarti bahwa keberhasilan dalam tercapainya tujuan pendidikan bergantung pada proses belajar mengajar. Proses pembelajaran dapat dilakukan dimana saja. Sekolah merupakan salah satu tempat yang berperan penting dalam proses pembelajaran tersebut, khususnya di dalam kelas. Dalam hal ini proses pembelajaran yang dilakukan di kelas harus berorientasi pada peserta didik (student centered), karena pembelajaran yang berorientasi pada peserta didik dapat meningkatkan pemahaman, keaktifan, keterampilan berpikir kritis, serta dapat meningkatkan hasil belajar peserta didik. Khususnya untuk mata pelajaran kimia, Kimia adalah ilmu yang mencari jawaban atas pertanyaan apa, mengapa, dan bagaimana gejala-gejala alam yang berkaitan dengan komposisi, struktur dan sifat, perubahan, dinamika, dan energetika zat (Badan Standar Nasional Pendidikan, 2006:177). Fenomena yang abstrak, kompleks, dan tidak teramati ini menjadi salah satu hal yang mengakibatkan kimia sulit untuk dipahami oleh sebagian peserta didik sehingga orientasi terhadap peserta didik sangat diperlukan guna mengetahui daya serap materi terhadap peserta didik. Dengan memahami gaya belajar peserta didik dapat meningkatkan pemahaman peserta didik pada konsep teori berdasarkan gaya belajarnya masingmasing.

Jika keberhasilan dalam tercapainya tujuan pendidikan bergantung pada kegiatan belajar mengajar, maka keberhasilan proses belajar mengajar itu sendiri tidak bisa lepas dari gaya belajar peserta didik.

Cara memproses informasi yang diperoleh dikenal dengan istilah gaya belajar. Beberapa ahli membagi gaya belajar melalui perspektif yang bervariasi sehingga didapatkan varian-varian pembagian gaya belajar.

Salah satunya yaitu gaya belajar oleh David Kolb yang lebih dikenal dengan gaya belajar model Kolb. Gaya belajar model Kolb dipilih dan digunakan oleh seseorang dalam menerima informasi dari lingkungannya dan memproses informasi, karena gaya belajar model ini lebih menekankan pola-pola perilaku atau sikap seseorang dalam menerima dan memproses informasi dari lingkungan. Berdasarkan hasil tes kemampuan spasial yang telah dilaksanakan di MAN II Yogyakarta pada bulan April 2017, dari 27 peserta didik terdapat 22 peserta didik yang menjawab 
hasil tes dengan benar semua mendapat nilai 100,3 peserta didik mendapat nilai 80,1 peserta didik mendapat nilai 60 dan 1 peserta didik mendapat nilai 20. Tes ini mengungkap sesuatu yang berhubungan dengan benda-benda yang konkret melalui visualisasi. Hasil tes dapat mengungkapkan bagaimana baiknya seseorang dapat membayangkan atau membentuk gambar-gambar mental dari objek-objek padat hanya dengan melihat rencana-rencana di atas kertas yang rata (flat paper plans), dan bagaimana baiknya seseorang berpikir dalam tiga dimensi (Dewa, 2009:134).

Dari hasil wawancara dengan peserta didik kelas XI MIPA 1 MAN II Yogyakarta dapat disimpulkan bahwa cara mengajar yang dilakukan oleh pendidik cenderung menggunakan aktivitas visual, sementara peserta didik mempunyai gaya belajar yang berbeda-beda. Peserta didik mempunyai gaya belajar yang alami dan nyaman, ketika dipaksa untuk belajar dengan cara lain maka akan timbul rasa frustasi sehingga pembelajaran akan menjadi sulit. Berdasarkan hasil tes kemampuan spasial peserta didik $81,5 \%$ memiliki nilai yang tinggi tetapi nilai ulangan harian peserta didik 55,8\% dibawah nilai KKM materi hidrokarbon. Seharusnya jika kemampuan spasial tinggi maka akan berpengaruh pada prestasi belajar seperti penelitian yang dilakukan oleh Muhamad Ghoni Rif'an (2011) mengenai pengaruh kemampuan spasial terhadap prestasi belajar matematika yang menunjukkan bahwa ada pengaruh signifikan antara kemampuan spasial peserta didik terhadap prestasi belajar. Peserta didik belum menyadari gaya belajar yang mereka miliki sehingga mereka belum bisa memaksimalkan cara belajarnya, terbukti dari masih adanya peserta didik yang menyibukkan diri dengan ngobrol sesama teman, bermain hp, serta tidur dikelas sewaktu pendidik menerangkan pelajaran. Maka dari itu pendidik harus memahami gaya belajar peserta didiknya agar dapat meningkatkan hasil belajar peserta didik pada mata pelajaran kimia. Gaya belajar diyakini dapat meningkatkan hasil belajar peserta didik. Berdasarkan pemaparan latar belakang tersebut, peneliti akan mengidentifikasi gaya belajar model Kolb untuk melihat kecenderungan gaya belajar peserta didik dalam proses pembelajaran kimia. Dengan identifikasi gaya belajar ini pendidik dapat menerapkan gaya belajar yang sesuai dengan peserta didiknya sehingga pelajaran kimia mudah diterima untuk mencapai hasil belajar yang maksimal.

\section{METODE PENELITIAN}

\section{Desain Penelitian}

Metode yang digunakan dalam penelitian ini adalah metode deskriptif 
dengan pendekatan kuantitatif, yaitu penelitian yang kemudian diolah dan dianalisis untuk diambil kesimpulan.

\section{Tempat dan Waktu Penelitian}

Tempat penelitian dilaksanakan yaitu di MAN II Yogyakarta. Waktu Penelitian dilaksanakan sejak disetujui proposal ini dan sampai selesainya perijinan, adapun penelitian dilaksanakan pada bulan Mei 2017.

\section{Instrumen Penelitian}

Instrumen yang digunakan pada penelitian ini yaitu berupa lembar angket KLSI (Kolb Learning Style Inventory).

\section{Teknik Pengumpulan Data}

Teknik pengumpulan data yang digunakan untuk mendapatkan data dalam penelitian ini yaitu teknik non test. Teknik non test pada penelitian ini yaitu angket, wawancara, dan studi dokumentasi.

\section{Teknik Analisis Data}

Analisis data merupakan proses mencari dan menyusun secara sistematis data yang diperoleh dari hasil wawancara, catatan lapangan dan dokumentasi dengan cara mengorganisasikan data ke dalam kategori, menjabarkan ke dalam unit-unit, melakukan sintesa, menyusun ke dalam pola, memilih mana yang penting dan yang akan dipelajari dan membuat kesimpulan sehingga mudah dipahami oleh diri sendiri maupun orang lain

Analisis data dalam penelitian ini menggunakan analisis deskriptif yaitu dengan menggunakan penafsiran data berdasarkan perhitungan persentase (\%) gaya belajar peserta didik. Cara yang digunakan ialah dengan menghitung jumlah pernyataan dari peserta didik yang menjawab ya dari keseluruhan pernyataan angket KLSI (Kolb Learning Style Inventory).

\section{HASIL DAN PEMBAHASAN}

Penelitian ini dilakukan di MAN II Yogyakarta dengan subyek penelitian sebanyak 52 peserta didik kelas XI MIPA MAN II Yogyakarta tahun ajaran 2016/2017. Penelitian juga dilakukan di 6 sekolah yang ada di Yogyakarta yaitu MAN 4 Bantul, MAN 2 Sleman, SMA N 2 Wates, SMA N 5 Yogyakarta, SMA IT Abu Bakar Yogyakarta, dan SMA 1 Kasihan Bantul. Penelitian di 6 sekolah ini menjadi data tambahan sebbagai penunjang keabsahan data gaya belajar peserta didik. Penelitian dilaksanakan pada bulan Mei 2017. Data penelitian diperoleh dari hasil penyebaran angket. Pengumpulan data dilakukan setelah instrumen penelitian teruji validitas. Instrumen angket dikonsultasikan kepada dosen ahli sebelum disebar untuk mengetahui validitas instrumen. 
Angket digunakan untuk memperoleh data gaya belajar dari peserta didik. Angket gaya belajar model Kolb memiliki empat aspek yaitu pengalaman konkrit/concrete experience (CE), pengalaman reflektif/reflective observation (RO), konseptualisasi abstrak/abstract conceptualization (AC), dan eksperimentasi aktif/active experimentation (AE). Dari keempat aspek tersebut jika di kombinasikan dapat membentuk empat gaya belajar model Kolb yaitu gaya belajar diverger, gaya belajar assimilator, gaya belajar converger dan gaya belajar accommodator. Selanjutnya pemberian skor atas alternatif jawaban yang telah diberikan oleh responden dengan ketentuan skor 1 untuk jawaban "Ya" dan skor 0 untuk jawaban "Tidak".

Jumlah pernyataan untuk keempat aspek gaya belajar model Kolb masingmasing 10 butir sehingga diperoleh skor tertinggi 10 dan skor terendah 0 .

Tujuan dari penelitian ini adalah untuk mengetahui jumlah persentase peserta didik yang termasuk dalam gaya belajar model Kolb tipe diverger, assimilator, converger, accomodator dan mengetahui korelasi antara kemampuan spasial dan gaya belajar peserta didik. Hasil penelitian menunjukkan bahwa setiap peserta didik memiliki kecenderungan pada salah satu gaya belajar model Kolb yaitu gaya belajar diverger, gaya belajar assimilator, gaya belajar converger dan gaya belajar accomodator.

Jumlah persentase peserta didik yang termasuk dalam gaya belajar model Kolb tipe diverger, assimilator, converger, accommodator

Berdasarkan penelitian awal di MAN II Yogyakarta pendidik cenderung menggunakan aktivitas visual pada mata pelajaran kimia, sementara peserta didik mempunyai gaya belajar yang berbedabeda. Diketahui bahwa 55,8\% peserta didik memiliki nilai KKM materi hidrokarbon yang rendah, sedangkan berdasarkan tes kemampuan spasial $81,5 \%$ peserta didik memiliki nilai yang tinggi. Berdasarkan hasil tes kemampuan spasial yang telah dilaksanakan di MAN II Yogyakarta pada bulan April 2017, dari 27 peserta didik kelas XI MIPA 1 terdapat 22 peserta didik yang menjawab benar semua mendapat nilai 100, 3 peserta didik yang mendapat nilai 80,1 peserta didik mendapat nilai 60 dan 1 peserta didik mendapat 40. Tes ini dapat mengungkap sesuatu yang berhubungan dengan bendabenda yang konkret melalui visualisasi. Dari hasil tes tersebut dapat dilihat bagaimana peserta didik dapat membayangkan atau membentuk gambar dengan berpikir dalam tiga dimensi. Seharusnya jika kemampuan spasial tinggi 
maka akan berpengaruh pada prestasi belajar. Namun di kelas XI MIPA MAN II Yogyakarta kemampuan spasial tinggi tetapi nilai KKM kimia materi hidrokarbon rata-rata di bawah KKM. Setelah dilakukan wawancara dengan peserta didik kelas XI MIPA 1 pada tanggal 20 februari 2017 pukul 12.15, pendidik cenderung menjelaskan secara visual saja sehingga peserta didik kurang aktif bertanya dan sulit memahami materi. Sedangkan didalam kelas terdapat peserta didik yang memiliki berbagai gaya belajar.

Berdasarkan hasil penelitian diketahui bahwa peserta didik kelas XI MIPA MAN II Yogyakarta tahun ajaran 2016/2017 yang cenderung memiliki gaya belajar diverger lebih memiliki minat budaya yang sangat luas serta senang mengumpulkan informasi. Peserta didik memiliki minat sosial yang tinggi, cenderung imajinatif, dan perasaannya amat peka. Dalam pembelajaran di kelas, peserta didik dengan gaya belajar ini lebih suka bekerja dalam kelompok dan menerima umpan balik yang bersifat personal. Peserta didik mampu mendengar dengan pikiran yang terbuka. Gaya belajar model Kolb yang kedua yaitu assimilator, peserta didik yang memiliki gaya belajar ini terampil dalam mengolah banyak informasi serta menempatkannya ke dalam bentuk yang pasti dan logis. Peserta didik kurang berfokus pada manusia tetapi lebih berminat pada ide dan konsep abstrak.
Peserta didik dengan gaya belajar ini lebih mementingkan keunggulan logis sebuah teori daripada nilai praktisnya. Dalam pembelajaran di kelas, peserta didik lebih suka membaca, mengajar, mengeksplorasi model analitis, dan memanfaatkan waktu untuk memikirkan berbagai hal secara mendalam.

Gaya belajar converger, ketika pembelajaran di kelas peserta didik cenderung melakukan eksperimen dengan ide baru melakukan eksperimen dengan ide baru Peserta didik dengan gaya belajar ini baik dalam menemukan kegunaan praktis dari ide dan teori. Peserta didik mampu memecahkan masalah dan mengambil keputusan secara efektif. Peserta didik lebih suka menangani masalah dan tugastugas teknis daripada isu sosial dan interpersonal. Gaya belajar yang terakhir yaitu gaya belajar accomodator. Peserta didik memiliki keunggulan untuk belajar dari pengalaman langsung. Peserta didik suka mengambil tindakan dan melibatkan diri dalam situasi baru yang menantang. Saat menghadapi persoalan, peserta didik dengan gaya belajar ini lebih mengandalkan pada informasi dari orang lain daripada dari pemikirannya sendiri. Dalam pembelajaran di kelas, peserta didik lebih suka bekerja dengan orang lain untuk menyelesaikan tugas, menetapkan tujuan, melakukan kerja lapangan, serta menguji bermacam-macam pemecahan suatu masalah. 
Jika dirangkum secara keseluruhan peserta didik kelas XI MIPA MAN II Yogyakarta tahun ajaran 2016/2017 memiliki beragam gaya belajar, peserta didik memiliki sikap mudah merespon apa yang disampaikan pendidik dan teman. Peserta didik lebih terbuka dan mau menerima kritik dan saran untuk perbaikan. Peserta didik juga memiliki kepedulian terhadap sesamanya dan mudah bergaul. Peserta didik lebih senang melakukan diskusi secara berkelompok untuk memahami materi pelajaran kimia dibandingkan dengan selalu mendengarkan penjelasan materi kimia oleh pendidik

\section{Korelasi antara kemampuan spasial dan gaya belajar peserta didik}

Identifikasi gaya belajar in
menggunakan angket
Learning Style Inventory). Angket KLSI efektif digunakan untuk mengetahui gaya belajar peserta didik yang lebih ingin memahami dirinya. Pentingnya identifikasi gaya belajar ini dianggap penting seperti yang diungkapkan oleh Ibu Dra. $\mathrm{Hj}$. Han'ah Hanum selaku guru kimia kelas XI MIPA 1 dan XI MIPA 2 MAN II Yogyakarta pada saat wawancara tanggal 31 Mei 2017. Beliau mengungkapkan bahwa terjadi perubahan pola belajar ketika pergantian kurikulum. Hal tersebut berpengaruh pada gaya belajar peserta didik, namun peserta didik dapat segera menyesuaikan kembali dalam proses pembelajaran. Jika gaya belajar peserta didik dianalisis dan diperbaiki maka dapat meningkatkan hasil pelajar peserta didik. Pengaruh positif gaya belajar adalah prestasi akademik membaik, tingkat kehadiran membaik, disiplin juga membaik dan problem perilaku berkurang (Gunawan, 2006:85).

Pengetahuan pendidik mengenai gaya belajar dapat membantu para pendidik melayani sebaik mungkin kebutuhan individual setiap peserta didik. Oleh karena itu, perlu adanya bimbingan mengenai bagaimana cara belajar yang baik yang sesuai dengan kepribadian peserta didik sehingga mampu mengembangkan jiwa yang intelektual dan meningkatkan hasil belajar. Peran pendidik sangat besar terkait peningkatan hasil hasil belajar, karena waktu belajar peserta didik sebagian besar bersama pendidik di sekolah. Tantangan terbesar guru yaitu menemukan cara untuk membuat semua peserta didik berhasil dan sukses. Namun tidak dapat dipungkiri bahwa pendidik tidak dapat menjangkau peserta didik satu demi satu untuk menyelesaikan masalah belajar yang dimiliki. Beberapa pendidik memilih untuk tidak peduli mengenai keberagaman gaya belajar yang dimiliki peserta didik. Pendidik mengabaikan masalah tersebut dan memberi pendekatan dengan menyamaratakan semua peserta didik. Efek dari hal tersebut akan membuat beberapa peserta didik frustasi. Untuk 
pendidik yang menyadari pentingnya kesesuaian gaya mengajar dengan gaya belajar peserta didik, mereka mulai mengubah kepribadian untuk beradaptasi dengan gaya belajar peserta didik.

Kemampuan spasial diperlukan adanya pemahaman perspektif, bentukbentuk geometris, menghubungkan konsep visual. Faktor- faktor tersebut juga diperlukan dalam menentukan gaya belajar model Kolb pada mata pelajaran kimia. Menurut Kolb (dalam Nasution, 2015:110113) menyatakan bahwa gaya belajar dapat ditentukan dari segi-segi pengalaman konkrit, pemahaman perspektif, analisis logis dan melalui tindakan yang cenderung kuat. Sehingga kemampuan spasial dan gaya belajar saling berkaitan. Kemampuan spasial yang merupakan aspek dari kognisi berkembang sejalan dengan perkembangan kognitif yang dapat meningkatkan hasil belajar peserta didik (Piaget dan Inhelder:1971). Sehingga untuk meningkatkan hasil belajar peserta didik khususnya pada mata pelajaran kimia dibutuhkan kemampuan spasial dan dapat dilakukan identifikasi gaya belajar model Kolb.

Hasil penelitian pada identifikasi gaya belajar model Kolb terhadap peserta didik pada mata pelajaran kimia kelas XI semester gasal MAN II Yogyakarta tahun ajaran 2016/2017 dengan menggunakan angket KLSI, wawancara dan studi dokumentasi menunjukkan bahwa peserta didik dengan gaya belajar diverger sebanyak 17 peserta didik atau 32,6\%, gaya belajar assimilator sebanyak 19 peserta didik atau 36,5\%, gaya belajar converger sebanyak 11 peserta didik atau $21,2 \%$ dan gaya belajar accomodator sebanyak 5 peserta didik atau 9,6\%. Hasil penelitian pada 6 Sekolah di Yogyakarta dengan menggunakan angket KLSI diperoleh peserta didik dengan gaya belajar diverger sebanyak 93 peserta didik atau $34,4 \% \%$, gaya belajar assimilator sebanyak 96 peserta didik atau 35,5\%, gaya belajar converger sebanyak 53 peserta didik atau 19,6\% dan gaya belajar accomodator sebanyak 28 peserta didik atau 10,3\%. Berdasarkan hasil penelitian di MAN II Yogyakarta dan 6 Sekolah di Yogyakarta menunjukkan bahwa mayoritas peserta didik memiliki gaya belajar assimilator, peserta didik lebih suka membaca, memiliki banyak sumber informasi kimia dari buku maupun internet, serta suka menyelesaikan soalsoal kimia dan mengerjakan laporan praktikum kimia dengan lengkap. Terdapat korelasi kemampuan spasial kimia dengan gaya belajar yaitu ditunjukkan dengan 19 peserta didik dengan gaya belajar assimilator yang memiliki nilai kemampuan spasial dan ulangan harian diatas nilai KKM materi hidrokarbon sesuai dengan cara mengajar yang dilakukan pendidik saat itu. 


\section{DAFTAR PUSTAKA}

Abdul, Hadis. (2008). Psikologi Dalam Pendidikan. Bandung: Alfabeta.

Adi, W., Gunawan. (2006). Genius Learning Strategy. Jakarta: PT. Gramedia.

Arsyad, Azhar. (2011). Media Pembelajaran cetakan ke-15. Jakarta: Rajawalli Pers.

Badan Standar Nasional Pendidikan. (2006). Panduan Penyusunan Kurikulumm Tingkat Satuan Pendidikan. Jakarta: Depdiknas.

Brady, J. E. (1999). Kimia Universitas Asas dan Struktur. Bandung: Binarupa Aksara.

Departemen Pendidikan Nasional. (2003). Undang-Undang Nomor 20 Tahun 2003, Tentang Sistem Pendidikan Nasional. Jakarta: Depdiknas.

Depdikbud. (1990). Kamus Besar Bahasa Indonesia. Jakarta: Balai Pustaka.

Hadi, Sutrisno, Metodologi Reseach, Jilid II, Yogyakarta: Andi Offset, 1991.

Hariwijaya, M.. 2005. Tes Intelegensi. Yogyakarta: Andi Offset.

Herlanti. (2006). Tanya Jawab Seputar Penelitian Pendidikan Sains. Jakarta : Jurusan Pendidikan IPA Fakultas Tarbiyah dan Ilmu Keguruan Universitas Islam Negeri Syarif Hidayatullah Jakarta.

Husein, Umar. (2003). Metodologi Penelitian Untuk Skripsi dan Tesis Bisnis. Jakarta: PT. Gramedia Pustaka.
Jean Piaget \& B. Inhelder. (1971). Mental Imageryin child. New York: Basic Books.

Kustandi dan Sutjipto. (2011). Media Pembelajaran Manual dan Digital. Bogor : Ghalia Indonesia.

Masykur, M. (2007). Mathematical Intelligence. Yogyakarta: Ar-Ruzz Media. Middlecamp, C. dan Kean, E. (1985). Panduan Belajar Kimia Dasar (Alih bahasa: A.H Pudjaatmaka). Jakarta: PT. Gramedia.

Mulyana, Deddy. (2005). Ilmu Komunikasi Suatu Pengantar. Bandung: Remaja Rosdakarya.

Nasution. (2008). Berbagai Pendekatan dalam Proses Belajar Mengajar. Jakarta: PT Bumi Aksara.

Nasution, Nur. (2015). Manajemen Mutu Terpadu. Bogor: Ghalia Indonesia.

Ngalim, Purwanto. (1991). Psikologi Pendidikan. Bandung: Remaja Karya.

Sugiyono. (2009). Metode Penelitian Pendidikan Pendekatan Kuantitatif, Kualitatif, dan $R \& D$. Bandung: Alfabeta.

Sukardi, Dewa Ketut. (2009). Analisis Tes Psikologi Dalam Penyelenggaraan Bimbingan di Sekolah. Jakarta: Rineka Cipta.

Sukiman. (2012). Pengembangan Media Pembelajaran. Yogyakarta: Pustaka Insan Madani

Thomas, Amstrong. (2002). Setiap Anak Cerdas. Panduan Membantu Anak Belajar dengan Memanfaatkan Kecerdasan Majemuk. Jakarta: Gramedia.

Tresna, Sastrawijaya. (1998). Proses Belajar Mengajar Kimia. Jakarta: Depdikbud. 